\title{
Simulering gjør sykepleierstudenter tryggere på å behandle meningitt
}

Studenter som lærer å behandle pasienter med meningitt gjennom praktisk фvelse, får $\varnothing \mathrm{kt}$ kunnskap og mestringstro. Men simuleringen kan bli enda bedre, viser denne unders $\varnothing$ kelsen.

Randi Gunveig Bratland

Førstelektor

Sykepleierutdanningen, Institutt for helse- og omsorgsfag, Universitetet i Tromsø, Campus Hammerfest

Solveig Johanne Kristoffersen

Universitetslektor

Sykepleierutdanningen, Institutt for helse- og omsorgsfag, Universitetet i Tromsø, Campus Hammerfest

\section{Undervisning Observasjon Simulering}


Som lærere ved sykepleiestudiet ved UiT - Norges arktiske universitet har vi gjort et fors $\varnothing \mathrm{k}$ med simulering i patologiundervisningen. Vi har samlet data fra to kull med studenter for å utvikle kvaliteten på hvordan vi instruerer under simuleringen. Vi har vært mest opptatt av hjernehinnebetennelse (meningitt). Våre data gir støtte til at bachelorstudenter i sykepleie oppnår bedre kunnskaper og dypere forståelse for sykdommen etter simulering. Men det bør unders $\varnothing$ kes nærmere hvordan studentene kan forberedes på at det vil skje dramatiske endringer i de vitale målingene under simuleringen. I ettertid ser vi behovet for at studentene får gjenta simuleringen i studentstyrte grupper uten lærer til stede, og at de får individuelle tilbakemeldinger etter kunnskapstesten.

Et landsomfattende tilsyn i norske, somatiske sykehus har vist at sepsispasienter ofte må vente for lenge på legeunders $\varnothing$ kelse, og antibiotikabehandlingen kommer derfor for sent i gang (1-3). Sykepleiere står sentralt i mottak av kritisk syke pasienter i sykehus og distrikt, og må derfor være oppdaterte i forhold til å ivareta pasientsikkerheten (3). Det er viktig at alle sykepleierstudenter lærer hva som skjer når tilstanden forverres til sepsis.

Simulering kan være en aktuell undervisningsmetode i denne forbindelse (4). I studien er vi interessert i å finne ut hvordan instruksjonskvaliteten i simuleringen kan utvikles i en klasse med rundt 40 til 60 studenter, fordelt på sju grupper og to faglærere.

\section{Hva er instruksjonskvalitet?}

Et bestemt mønster av instruksjonsvariabler og forhold som påvirker instruksjon, og som påvirker elevenes prestasjon positivt. For eksempel instruksjonsklarhet, kognitiv aktivering, diskursegenskaper og st $\varnothing t t e n d e$ miljø.

Kilde: Klette K, Blikstad-Balas M, Roe A (20)

Vi har derfor gjort et fors $\varnothing \mathrm{k}$ med simulering i forhold til en pasient med meningitt, i to kull, og samlet data fra en test av hvilke kunnskaper studentene hadde om meningitt (kull A) og en test av studentens utbytte av simuleringen (kull B).

\section{Meningitt kan føre til sepsis}


Det unike ved meningitt er rask sykdomsutvikling som kan føre til sepsis med dødelighet på 10-25 prosent (5). Meningitt må behandles i sykehus, men helsepersonell må ha innsikt i tidlige kliniske tegn for å sikre riktig behandling (6), uansett hvor de møter pasienter med symptomer på meningitt.

De må også vite at etter norske regler skal pasienten ha antibiotika under transporten til sykehus hvis reisetiden er mer enn tretti minutter (5).

\section{Studentene lærer om meningitt}

Sykepleierstudenter kan beskrives som nybegynnere i denne sammenhengen, derfor må de handle ut fra regler (7). For å kunne oppdage forverring i pasientens tilstand finnes det $\mathrm{i}$ dag en rekke kriterier som SIRS, Q-Sofa, Glasgow Coma Scale som en kan si er «generelle regler» (8-10).

Etter hvert må studentene utvikle evnen til å prioritere tiltak også ut fra kunnskaper om og forståelse for den spesifikke sykdommen.

\section{$\equiv$ «Vi ønsker at studentene skal begynne å bygge opp en dypere forståelse av meningitt.»}

Vi ønsker at studentene skal begynne å bygge opp en dypere forståelse av meningitt. Studentene trenger en forståelse for hva forverringen av sykdommen kan innebære. Vi har derfor organisert et undervisningsopplegg som består av forelesninger kombinert med simulering, der vi legger vekt på simuleringsdelen.

\section{De øver seg på Anne-dukker}

Simulering er en måte å benytte ekte kliniske hendelser for å st $\varnothing$ tte og vurdere studenter. Simulering kan utformes på mange og ulike måter (11). Vår studie handler om scenariobasert simulering med bruk av alminnelige Annedukker (12).

Mange studenter liker simuleringsmetoden, samtidig foreligger det få funn i litteraturen som tyder på at simulering kan redusere teori-praksisgapet (13). Men simulering har sin plass i forberedelsen til praksis (14). Litteraturen viser at simulering kan føre til dypere forståelse av en infeksjonssykdom (15). 


\section{Vi ville finne ut hvordan simuleringen kan bli bedre}

I studien er vi interessert i å finne ut: Hvordan kan vi utvikle kvaliteten på instruksjonene i simuleringen slik at alle studenter i klassen oppnår en dypere forståelse av en alvorlig sykdom som hjernehinnebetennelse?

Vårt undervisningsopplegg hviler på sosial læringsteori beskrevet av Bandura (16) og vektlegger kognitive, sosiale og affektive aspekter ved læring. Sosial læringsteori innbefatter begrepet mestringstro, det vil si: Å ha tro på egen evne til å organisere og gjennomføre handlingene som kreves, i tillegg til å ha tro på at jeg vil håndtere situasjoner som kommer (17).

Unders $\varnothing$ kelsen av to kull er basert på prosessorientert evaluering etter Stake (18). Kull A besvarte en kunnskapstest (resultatvurdering). Og studentene i kull B besvarte et spørreskjema om utbytte (prosessvurdering). Svarene ble behandlet som en tekst og analysert for meningsinnhold (19). I prosessevalueringen inngikk også lærernes loggføring av sin deltakende observasjon.

Prosessorientert evaluering innebærer at man søker etter kvalitet og representasjonen av kvalitet i et program (18). Prosessorientert evaluering betyr også at forskeren vurderer både ut fra egne tolkninger av situasjonen og etter kriterier for hva som er god kvalitet.

\section{Kriterier for å vurdere kvaliteten på simuleringen}

For å vurdere kvaliteten på simuleringen knyttes det an til begrepet instruksjonskvalitet som er blitt definert som: Et bestemt mønster av instruksjonsvariabler og forhold som påvirker instruksjon, og som påvirker elevenes prestasjon positivt. Konsensusbaserte kriterier for instruksjonskvalitet er blant annet beskrevet i Klette og medarbeidere (20).

Kriterier for instruksjonskvalitet (20):

- Instruksjonsklarhet: Veileder gir tydelig instruksjon, klare mål, formidler faget klart og utvetydig, underviser i relevante læringsstrategier og viser tydelig hvordan nye ferdigheter skal utføres.

- Kognitiv aktivering: Studentene får dypere forståelse gjennom refleksjon over begreper, studenter blir utfordret og møter motsigelser. 
- Diskursegenskaper: Studentene deltar i faglig diskusjon og blir lyttet til av læreren.

- Støttende miljø: Veiledere og medstudenter gir positive og konstruktive tilbakemeldinger, det er støttende lærerstudent-relasjoner og alle deltakere har en omsorgsfull atferd.

Prosjektet er godkjent av NSD - Norsk senter for forskningsdata. Interne retningslinjer for melding av unders $\varnothing$ kelser på Institutt for helse og omsorgsfag på UiT Norges arktiske universitet er fulgt.

Undervisningsopplegget er et fors $\varnothing \mathrm{k}$, og hører ikke med til den ordinære fagplanen. Instituttleder har godkjent gjennomføringen, samt at studentene har kvittert for frivillig deltakelse og informert samtykke erklæring.

\section{Slik foregikk undervisningen}

Undervisningsopplegget ble gjennomført ved studiestedet IHO i Hammerfest. Det var totalt 101 studenter i 3. semester som deltok.

Målet er at studentene skal kunne forklare hvordan sykdom og sykdomsprosesser oppstår og kommer til uttrykk hos mennesker, og forklare og beskrive ulike infeksjonssykdommer, hygieniske prinsipper og tiltak. Pensum beskriver nærmere hvilken kunnskap om meningitt studentene skal ha (21-23).

Det undervises først i sykdomslære gjennom forelesninger, deretter får studentene delta i praksisforberedende undervisning på øvingsrom, og her foregår simuleringen.

To lærere gjennomførte simulering for hver sine grupper på seks til åtte studenter. Øvelsen varte en skoletime. To klasser gjennomførte $\varnothing$ velsen med ett års mellomrom.

Både målene i fagplanen og pensum var noe utilstrekkelig med tanke på å gi studentene et grunnlag for å forstå hvordan man tidlig kan oppdage forverringen ved meningitt. Derfor laget vi en kortfattet sjekkliste på bakgrunn av pensum. Denne inneholdt blant annet Glasgow Coma Scale og SIRSkriteriene for observasjon av kritisk syke.

\section{Sykehistorien}

Studentene benyttet en sykehistorie utarbeidet på bakgrunn av lærernes sykepleiererfaringer fra infeksjonsavdelingen og med inspirasjon fra Campell og Daley (24). 
Studentene fikk arbeidsoppgaver til en case der de skulle vise gjennom handlinger og kommunikasjon hvordan de ville møtt en pasient med meningitt og hvilke observasjoner de ville foretatt:

«Mann, 18 år, er innlagt på medisinsk avdeling med feber og nedsatt allmenntilstand. Pasienten er isolert på grunn av ukjent infeksjonsfokus. Foreløpig er ikke medikamentell behandling iverksatt. Dere skal på kveldsvakt og får rapport fra dagvakten. Under rapporten blir det klart at mistanken vender seg til meningitt. Det er planlagt diverse unders $\varnothing$ kelser. En sykepleier og en sykepleierstudent skal ha ansvaret for denne pasienten. En hjelpepleier tilbyr seg også å være tilgjengelig om noe skulle skje med pasienten. Dere gjør dere klare for å gå inn til pasienten så fort rapporten er over.»

Studentene fikk beskjed om å fordele rollene; sykepleier, sykepleierstudent og hjelpepleier. To studenter skulle være observatører. De første som kommer inn til pasienten er en sykepleier og en sykepleierstudent. Studentene får nå fem minutter på å planlegge og fordele roller og bli enige om hvem som skal dokumentere observasjoner de gjør.

Observatørene fordeler oppgavene seg imellom der den ene observerer samspillet mellom aktørene og hvordan de observerer pasienten og den andre studerer kommunikasjonen mellom helsearbeiderne og pasienten.

Etter gjennomføring av simuleringen, ble det gitt en kunnskapstest for kull A.

Tabell 1 a og b: Forverring av pasientens situasjon. Status for pasientens respirasjon, sirkulasjon, nevrologisk status og eliminasjon før og i løpet av simuleringen

\begin{tabular}{|c|c|c|c|c|}
\hline & $\begin{array}{l}\text { Endringer } \\
\text { i sirkulasjon }\end{array}$ & $\begin{array}{l}\text { Endringer } \\
\text { i respirasjon }\end{array}$ & $\begin{array}{l}\text { Endringer } \\
\text { i nevrologisk status }\end{array}$ & $\begin{array}{l}\text { Endringer i eliminasjon, } \\
\text { væske og elektrolytter }\end{array}$ \\
\hline $\begin{array}{l}\text { a) Opplysninger om } \\
\text { vitale tegn gitt studen- } \\
\text { tene før simuleringen }\end{array}$ & $\begin{array}{l}\text { BP: } 130 / 80 \\
\text { puls: } 88 \text { regular } \\
\text { Rectal temperatur: } \\
38,8 \text { Co } \\
\text { Hud: Varm og tørr. }\end{array}$ & $\begin{array}{l}\text { Respirasjons- } \\
\text { frekvensen er 19/min } \\
\text { og ubesværet }\end{array}$ & $\begin{array}{l}\text { Våken, klar og } \\
\text { orientert, beveger } \\
\text { alle ekstremitetene, } \\
\text { side lik kraft, god } \\
\text { sensibilitet. Pupiller } \\
\text { lysreaktive og sidelike. }\end{array}$ & $\begin{array}{l}\text { Har kastet opp tre ganger } \\
\text { på formiddagen. }\end{array}$ \\
\hline $\begin{array}{l}\text { b) Første måling som } \\
\text { studentene gjør i løpet } \\
\text { av simuleringen }\end{array}$ & $\begin{array}{l}\text { BP: } 90 / 60 \\
\text { Puls: } 110 \\
\text { Hud: blek og klam }\end{array}$ & $\begin{array}{l}\text { Respirasjons- } \\
\text { frekvensen er } 26 / \mathrm{min} \\
\text { og overfladisk. }\end{array}$ & $\begin{array}{l}\text { Pasienten har } \\
\text { hodepine, noe } \\
\text { nakkestiv }\end{array}$ & $\begin{array}{l}\text { Urinen er sparsom } \\
\text { og bokkølfarget }\end{array}$ \\
\hline
\end{tabular}

Studentene fikk casen og ble brifet om status for pasienten før simuleringen (se tabell 1a). Deretter gjorde de sine egne unders $\varnothing$ kelser av Anne-dukken. Dette foregikk ved at læreren var dokkas «stemme» og svarte for pasienten. Læreren kunne også gi studentene informasjon om vitale tegn, når studentene unders $\varnothing$ kte dokka. Som det fremgår av tabell $\mathrm{lb}$ viste data en alvorlig forverring i pasientens situasjon. 


\section{Vurdering av instruksjonskvaliteten}

Instruksjonsklarheten i simuleringen er sett i forhold til resultatene i kunnskapstesten (kull A). Kunnskapstesten i kull A $(n=44)$ gjennomføres umiddelbart etter simuleringen.

Spørsmålene som ble stilt i kunnskapstesten var:

- Hva er meningitt? Forklar.

- Hvilke symptomer er mest fremtredende ved meningitt?

- Hvilke sykepleieobservasjoner er viktige når man har pasienter med meningitt?

- Hva skjer ved septisk sjokk?

- Når og hvor lenge skal pasienter med meningitt smitteisoleres?

- Hvordan vil du ivareta pasienters behov for trygghet under meningitt?

Studentene $(\mathrm{n}=44)$ brukte 15 til 20 minutter på å svare på spørsmålene i kunnskapstesten. Kunnskapstesten i kull A ble vurdert på samme måte som en eksamen ut fra pensum med karakterer A til F.

Svarprosenten på kunnskapstesten i kull A er på 88,6 prosent og det vurderer vi til å være en høy svarprosent. Ca. 11,4 prosent har ikke svart på testen.

Kunnskapstesten viser variasjon i kunnskapene etter simuleringen. Selv om studentene har brukt kun 20 minutter på spørsmålene så gir den et øyeblikksbilde av kunnskapene.

De fleste studentene fordeler seg på karakteren C og D. En liten gruppe fikk $\mathrm{B}$ eller $\mathrm{E}$. Men det manglet studenter på topp (A) og bunn (F) i karakterpyramiden. Det betyr at spørsmålene er vanskelige for studenter på dette nivået, siden ingen får toppkarakter, og at alle har hatt et visst utbytte, siden ingen studenter stryker. Totalt sett gir resultatene støtte til at simulering er en god metode på fagfeltet.

Tabell 2 Lærernes karakterfordeling på kunnskapstesten ( $n=44)$. Kull A.

\begin{tabular}{llllllll} 
Karakterfordeling & A & B & C & D & E & F & Ikke svart \\
\hline & $\mathrm{n}=0$ & $\mathrm{n}=5$ & $\mathrm{n}=17$ & $\mathrm{n}=11$ & $\mathrm{n}=6$ & $\mathrm{n}=0$ & $11,4 \%$ \\
& $0 \%$ & $11.3 \%$ & $38,63 \%$ & $25 \%$ & $13,63 \%$ & $0 \%$ &
\end{tabular}




\section{Studentene har varierende kunnskap om meningitt}

Studien viste at studentene kjenner til symptomene ved meningitt, men når det gjelder forståelse for den mulige forverringen, er det variasjon i kunnskapene. Vi fant at det var varierende kunnskap om blant annet observasjoner av respirasjon som er viktig på grunn av fare for komplikasjoner som sepsis, hjerneødem og herniering.

Hjerneødem gjør at hjernens hinner utvider seg og (5) respirasjonssenteret kan bli påvirket av det $\varnothing$ kte trykket som dannes $i$ hjernen, og det kan i verste fall være fare for respirasjonsstans. Respirasjonsfrekvensen kan være $\varnothing \mathrm{kt}$ på grunn av sepsisutvikling.

\section{$\equiv$ «Studenten bør vite at endringer i vitale tegn kan komme veldig hurtig.»}

Dersom studentene/sykepleierne bruker generelle vitalparametere $(8,10)$ uten kunnskap om sykdommen, risikerer de å undervurdere behovet for hyppig observasjon av vitale tegn. Ved mistanke om meningitt bør studenten vite at endringer i vitale tegn kan komme veldig hurtig og vil kreve kontinuerlig observasjon. Observasjonene foregår klinisk, uten bruk av scoop-overvåkning.

Etter simuleringen ga vi alle studentene beskjed om å lese mer om observasjoner av respirasjon.

\section{Studentene behøver individuelle tilbakemeldinger}

Kunnskapstesten ble gjort anonymt, og det var derfor ikke mulig å gi den enkelte student tilbakemelding om han eller hun svarte riktig eller galt.

I ettertid ser vi at studentene behøver individuelle tilbakemeldinger etter kunnskapstester, og at individuelle tilbakemeldinger kan være med å utvikle instruksjonsklarheten fordi studenten får vite hva de kan godt, og hva de må lese mer på.

For å bedre instruksjonsklarheten kan det være aktuelt å la studentene giennomføre simuleringen på nytt, og uten lærer, slik at de kan øve mer på forhold som var vanskelige å forstå (25). 


\section{Oppnår de mestringstro?}

Hva viser testen om utbytte for kull B? Hvilket utbytte mener studentene de har av å delta i simulering? Fører simuleringen til kognitiv aktivering? Er det mulig å skape diskurs og støttende miljø i gruppene?

Studentundersøkelsen tyder på at vi til en viss grad har oppnådd mestringstro hos studentene. Studentene i kull B fikk følgende spørsmål etter simuleringen: Hva slags utbytte har du hatt av å delta i simulering til en meningittpasient? Var det noe som burde vært gjort annerledes?

Tabell 3. Studenters egen beskrivelse av utbytte ved simulering $\left(n=57^{*}\right)$. Kull B

\begin{tabular}{l|l|l|l|l}
\hline Utbytte av & Lettere å lære når & Lærte mye om meningitt & Fikk bedre kunnskap om hvilke & Ble mer bevisst
\end{tabular} $\begin{array}{lllll}\text { simulering en så hva som hendte } & \text { som jeg ikke visste fra før } & \text { observasjoner som måtte gjøres } & \text { om hvor jeg sto faglig }\end{array}$

Tabell 3 viser at simuleringsopplegget har gitt studentene læringsutbytte (3). Svarprosenten er 59,3 prosent. Vårt resultat stemmer overens med andre forskeres funn som hevder at simulering fører til dypere forståelse av en sykdomsepisode $(12,14)$. Det var få kommentarer på hva som kunne vært gjort annerledes.

En student ville ha mer simulering, en annen $\varnothing$ nsket at flere kunne spille sykepleierrollen. En annen student ønsket at det skulle være mer likestilte roller slik at alle kan delta like mye. Likestilte roller var vanskelig å få til ut fra de tilgjengelige ressursene vi hadde.

\section{Skjer det en kognitiv aktivering hos studentene?}

Selv om studentene hadde fått utdelt en sjekkliste som inneholdt blant annet Glasgow Coma Scale og SIRSkriteriene for observasjon av kritisk syke (21-23), ble de overrasket da de opplevde at blodtrykket til pasienten faktisk sank i simuleringen. Dette tyder på at de ikke hadde forstått begrepet «blodtrykksfall» fullt ut før simuleringen. I evalueringen sier studentene at de forsto, når de så hva som hendte. 
De målte blodtrykket på Anne-dokka og fikk vite av læreren at nå var blodtrykket 90/60 mm hg (Se tabell 1). Overraskelsen og opplevelsen av utfordring, kombinert med tilbakemelding fra læreren, forårsaket en form for kognitiv aktivering hos mange av studentene. Dette kan tyde på at uansett hvor godt lærere forklarer observasjoner på forhånd, så forstår ikke studentene betydningen før de har fått erfare noen praktiske eksempler i simulering eller i praksis.

\section{De får reflektere over egen læring}

Diskusjonen foregikk mest i debrifingen etter gjennomføringen av scenarioet. Det viktigste var å tolke det som skjedde med pasienten, hvordan bruke sansene for å oppfatte at noe skjer: Hva skjer i verste fall nå

(14)? Observatørene kom med sin versjon, og de var positive til samspill, kommunikasjon og observasjoner.

Instruksjon i simuleringen må gi mulighet for en dialog der studentene kan bli utfordret, og bli bedt om å reflektere over egen læring og hvordan de forstår faglige sammenhenger.

\section{$\equiv$ 三Studenten ville vite mer om lærernes egne erfaringer med meningittpasienter.»}

Vi erfarte at studenten ville vite mer om lærernes egne erfaringer med meningittpasienter. Vi fortalte kort om hvor hurtig situasjonen kan endre seg i en negativ retning. For eksempel at pasienten kan få alvorlige krampeanfall, bli bevisstløs og bli avhengig av respiratorbehandling i en periode, eller at det ender fatalt. Vi tok opp betydningen av å se etter peteccier (hudblødninger) fordi det kan si noe om utvikling til meningokokksepsis (5).

Det må være rom for å stoppe simuleringen og forklare eksplisitt hva, hvorfor og hvordan vi vil at studenten skal observere. På samme måte som Mikkelsen 2008 (15) mener vi at en aktiv lærer er nødvendig for å oppnå faglig dialog. Dette står i motstrid til det Alinier og medarbeidere hevder (25), de mener at læreren skal ha en mer tilbaketrukket rolle. 
I vår simulering, med bruk av Anne-dukker, og med en så alvorlig diagnose, vil ikke studentene alltid være i stand til å prøve seg frem til riktig resultat. Her trengs det mer mestersvenn tilnærming (6), der studentene kan få arbeide på egen hånd etter at de har blitt veiledet av læreren i simuleringen, dette har ikke vi prøvd ut, men det er anbefalt av Sivertsen og medarbeidere (26).

\section{Oppnås et støttende miljø?}

Det er nødvendig å sørge for et st $\varnothing t t e n d e$ milj $\varnothing$ slik at studentene opplever mestringstro den dagen de møter pasienter i kritiske situasjoner. Når vi så nybegynnerfeil, prøvde vi å gi positive og konstruktive tilbakemeldinger på det arbeidet studentene gjorde. Disse nybegynnerfeilene gjaldt bruk av utstyr til oksygenbehandling og dokumentasjon av de data som de «fant» på dukken.

Samtidig er det viktig at studentene får se hva som kreves av en sykepleier i en slik livstruende situasjon. Vi burde kanskje ha forklart hele forløpet i simuleringen på forhånd, men da hadde noe av overraskelsesmomentet blitt borte. Som lærere fors $\varnothing$ kte vi gjennom simuleringen å skape en illusjon av farlige symptomer hos pasienten (4), studentunders $\varnothing$ kelsen viser at vi langt på vei oppnådde dette (se tabell 3 ).

\section{三 «Frykten kan ha sammenheng med hvordan de blir eksponert for hverandre og læreren i gruppene.»}

Det er diskutert om simulering kan føre til at studenter opplever frykt under simulering fordi de ikke strekker til eller ikke vil vise seg for andre (25). Frykten kan ha sammenheng med hvordan de blir eksponert for hverandre og læreren i gruppene, for eksempel via filmopptak (som vi ikke benyttet). For å utvikle et st $\varnothing t t e n d e$ milj $\varnothing$ må lærere sørge for at det er balanse mellom utfordring og opplevelsen av omsorgsfull atferd fra alle deltakere i simuleringen.

\section{Veien videre}

Begge studentunders $\varnothing$ kelsene gir st $\varnothing t t e$ til at studenter oppnår bedre kunnskaper, en dypere forståelse (20) og mestringstro (17) etter simulering. Det virker som mange profitterer på simuleringen, siden ingen stryker på kunnskapstesten. Samtidig viser studien at fagstoffet er vanskelig for nybegynnere siden ingen får toppkarakter. Observasjoner på respirasjon er et tema som må vektlegges ytterligere i sykepleierstudiet. 


\section{$\equiv$ «Studenter oppnår bedre kunnskaper, en dypere forståelse og mestringstro etter simulering.»}

I ettertid ser vi behovet for at studentene får gjenta simuleringen i studentstyrte grupper, uten lærer til stede, og at de får individuelle tilbakemeldinger etter kunnskapstesten.

Så å si alle studentene (kull B) som svarer på utbytteunders $\varnothing$ kelsen er forn $\varnothing \mathrm{yd}$ med læringsutbytte ved simulering, men det er en gruppe på ca. 40 prosent som ikke svarte. Årsaken til lav svarprosent kan være at det var frivillig å svare, men det kan også bety at vi må arbeide enda mer med opplegget. Det bør særlig undersøkes nærmere hvordan studentene kan forberedes på at det vil skje dramatiske endringer i de vitale målingene til pasienten under simuleringen.

Takk til studenter som deltok i prosjektet og avdelingens ledelse som ga oss mulighet til å prøve ut et nytt undervisningsopplegg. Takk til Grete Mehus for oppfølging av skrivearbeidet.

\section{Referanser}

1. Skrede S. Correct priorities in sepsis cases. Tidsskr Nor Laegeforen. 2019;139(9).

2. Helsetilsynet. Sepsis - ingen tid å miste. Oslo:

Helsetilsynet; 2018.

3. Aase K. Pasientsikkerhet: teori og praksis. 3. utg. Oslo: Universitetsforlaget; 2018.

4. Gaba D. The future vision of simulation in health care. Qual Saf Health Care. 2004;13:12-i10.

5. Norsk barnelegeforening. Meningokokksepsis. Oslo: Norsk Barnelegeforening; 2006. Tilgjengelig fra: https://www.helsebiblioteket.no/pediatriveiledere? menuitemkeylev1=\&menuitemkeylev2 $=6513 \&$ key (nedlastet 05.12.2019).

6. Skrede S, Sjursen H, Solberg CO. Behandling av akutt bakteriell meningitt. Tidsskr Nor Lægeforen. 2001;121(28):3306-9. 
7. Benner P. Fra novise til ekspert: dyktighet og styrke i klinisk sykepleiepraksis. Oslo/København: TANO

Munksgaard; 1995.

8. Subbe CP, Kruger M, Rutherford P, Gemmel L. Validation of a modified Early Warning Score in medical admissions. QJM. 2001; 94(10):521-6.

9. Deutschman CS, Singer M. Definitions for sepsis and septic shock-reply. JAMA. 2016;316(4):458-9.

10. Breivik S, Tymi A. Hva innebærer systematisk klinisk unders $\varnothing$ kelse i sykepleie? Sykepleien Forskning. 2013;8(4):324-32.

11. Cant RP, Cooper JS. Use of simulation-based learning in undergraduate nurse education: An umbrella systematic review. Nurse Educ Today. 2017;49:63-71.

12. Fagerli LB, Paulsen KM, Hjelmeland I, Hagen L. Å lære bort via pasientdukker [internett]. Oslo: Fontene; 17.03.2015 [oppdatert 27.08.2015; sitert 22.01.2020]. Tilgjengelig fra: https://fontene.no/fagartikler/a-lare-bort-via-pasientdukker6.47.226063.02ecdc59c9

13. Warren JN, Luctkar-Flude M, Godfrey C, Lukewich J. A systematic review of the effectiveness of simulation-based education on satisfaction and learning outcomes in nurse practitioner programs. Nurse Educ Today. 2016;46:99-108.

14 Kristoffersen SJ. Høyteknologisk simulering som praksisforberedende undervisningsform i

Bachelorutdanningen i sykepleie. Hvilken betydning har det for sykepleierstudentenes sykepleieutøvelse i praksis? (Masteroppgave). Troms $\varnothing$ : Universitetet i Troms $\varnothing ; 2016$.

15. Mikkelsen J, Reime MH, Harris AK. Nursing students' learning of managing cross-infections - scenario-based simulation training versus study groups. Nurse Educ Today. 2008;28(6):664-71.

16. Bandura A. Social foundations of thought and action: a social cognitive theory. Englewood Cliffs, New Jersey. USA, J. Prentice-Hall; 1986.

17. Bandura A, Estes WK. Self-efficacy: Toward a unifying theory of behavioral change. Psychological Review.

1977;84(2):191-215. 
18. Stake RE. Standards-based \& responsive evaluation.

California: Sage; 2004.

19. Kvale S, Brinkmann S, Torhell S-E. Den kvalitativa forskningsintervjun. Lund: Studentlitteratur; 2009.

20. Klette K, Blikstad-Balas M, Roe A. Linking instruction and student achievement. A research design for a new generation of classroom studies [internett]. Oslo: Acta Didactica Norge; 03.10.2017 [sitert 02.12.2019]. Tilgjengelig fra: https://journals.uio.no/adno/article/view/4729

21 Ørn S, Bach-Gansmo E. Sykdom og behandling. 2. utg. Oslo: Gyldendal Akademisk; 2016.

22. Almås H, Stubberud D-G, Grønseth R, Toverud KC.

Klinisk sykepleie: 1. 5. utg. Oslo: Gyldendal Akademisk; 2016.

23. Almås H, Stubberud D-G, Grønseth R, Toverud KC.

Klinisk sykepleie: 2. 5. utg. Oslo: Gyldendal Akademisk; 2016.

24. Campbell S, Daley K. Simulation scenarios for nursing educators: making it real. 2. utg. New York: Springer Publishing Company; 2012.

25. Alinier G, Hunt B, Gordon R, Harwood C. Effectiveness of intermediate-fidelity simulation training technology in undergraduate nursing education. J Adv Nurs. 2006;54(3):359-69.

26. Sivertsen N, McNeill L, Müller A. A redo station after debrief improves learning in undergraduate nursing simulation. Clinical simulation in nursing. 2016;12(11):469-72. 